\title{
Front Matter: Volume 9863
}

, "Front Matter: Volume 9863," Proc. SPIE 9863, Smart Biomedical and Physiological Sensor Technology XIII, 986301 (27 July 2016); doi: $10.1117 / 12.2244364$

SDIE Event: SPIE Commercial + Scientific Sensing and Imaging, 2016, Baltimore, MD, United States 


\title{
PROCEEDINGS OF SPIE
}

\section{Smart Biomedical and Physiological Sensor Technology XIII}

\author{
Brian M. Cullum \\ Douglas Kiehl \\ Eric S. McLamore \\ Editors
}

18-19 April 2016

Baltimore, Maryland, United States

Sponsored and Published by

SPIE 
The papers in this volume were part of the technical conference cited on the cover and title page. Papers were selected and subject to review by the editors and conference program committee. Some conference presentations may not be available for publication. Additional papers and presentation recordings may be available online in the SPIE Digital Library at SPIEDigitallibrary.org.

The papers reflect the work and thoughts of the authors and are published herein as submitted. The publisher is not responsible for the validity of the information or for any outcomes resulting from reliance thereon.

Please use the following format to cite material from these proceedings:

Author(s), "Title of Paper," in Smart Biomedical and Physiological Sensor Technology XIII, edited by Brian M. Cullum, Douglas Kiehl, Eric S. McLamore, Proceedings of SPIE Vol. 9863 (SPIE, Bellingham, WA, 2016) Six-digit Article CID Number.

ISSN: 0277-786X

ISSN: 1996-756X (electronic)

ISBN: 9781510601048

Published by

SPIE

P.O. Box 10, Bellingham, Washington 98227-0010 USA

Telephone +1 3606763290 (Pacific Time) · Fax +1 3606471445

SPIE.org

Copyright (C) 2016, Society of Photo-Optical Instrumentation Engineers.

Copying of material in this book for internal or personal use, or for the internal or personal use of specific clients, beyond the fair use provisions granted by the U.S. Copyright Law is authorized by SPIE subject to payment of copying fees. The Transactional Reporting Service base fee for this volume is $\$ 18.00$ per article (or portion thereof), which should be paid directly to the Copyright Clearance Center (CCC), 222 Rosewood Drive, Danvers, MA 01923. Payment may also be made electronically through CCC Online at copyright.com. Other copying for republication, resale, advertising or promotion, or any form of systematic or multiple reproduction of any material in this book is prohibited except with permission in writing from the publisher. The CCC fee code is 0277-786X/16/\$18.00.

Printed in the United States of America.

Publication of record for individual papers is online in the SPIE Digital Library.

\section{SPIE. DIGITAL}

Paper Numbering: Proceedings of SPIE follow an e-First publication model. A unique citation identifier (CID) number is assigned to each article at the time of publication. Utilization of CIDs allows articles to be fully citable as soon as they are published online, and connects the same identifier to all online and print versions of the publication. SPIE uses a six-digit CID article numbering system structured as follows:

- The first four digits correspond to the SPIE volume number.

- The last two digits indicate publication order within the volume using a Base 36 numbering system employing both numerals and letters. These two-number sets start with 00, 01, 02, 03, 04 , 05, 06, 07, 08, 09, OA, OB ... 0Z, followed by 10-1Z, 20-2Z, etc. The CID Number appears on each page of the manuscript. 


\title{
Contents
}

\author{
$\checkmark \quad$ Authors \\ vii Conference Committee
}

\section{SESSION 1 SMART MATERIALS FOR SENSING}

$986303 \quad$ Effect of pH on the morphology of kidney stones [9863-2]

986304 Growth mechanism of nanowires: binary and ternary chalcogenides [9863-3]

$986305 \quad$ Rapid discovery of peptide capture candidates with demonstrated specificity for structurally similar toxins (Invited Paper) (Best Paper Award) [9863-4]

\section{SESSION 2 BIOINSPIRED RECEPTORS AND SENSING PLATFORMS}

986308 Investigation of engineered bacterial adhesins for opportunity to interface cells with abiotic materials [9863-7]

986309 Bio-inspired patterned networks (BIPS) for development of wearable/disposable biosensors [9863-8]

\section{SESSION 3 ENABLING TECHNOLOGIES AND SENSING PLATFORMS}

9863 OB The development of Army relevant peptide-based surface enhanced Raman scattering (SERS) sensors for biological threat detection (Invited Paper) [9863-10]

9863 OC Characterization of analytical figures of merit of a sub-diffraction limited fiber bundle array for SERS imaging [9863-11]

$9863 \mathrm{OE} \quad$ Effect of platinum nanoparticle deposition parameters on hydrogen peroxide transduction for applications in wearable electrochemical glucose biosensors [9863-13]

\section{SESSION 4 BACTERIAL \& METABOLIC SENSING}

9863 OF Impedance biosensor for the rapid detection of Listeria spp. based on aptamer functionalized Pt-interdigitated microelectrodes array (Best Paper Award) [9863-14]

9863 0G Investigation of magnetic microdiscs for bacterial pathogen detection (Best Paper Award) [9863-15]

$9863 \mathrm{OH} \quad$ Dynamics of an electrochemical biosensor for the detection of toxic substances in water (Invited Paper) [9863-16] 
$986301 \quad$ Predictive modeling in Clostridium acetobutylicum fermentations employing Raman spectroscopy and multivariate data analysis for real-time culture monitoring [9863-17]

$98630 \mathrm{~J} \quad$ Modelling and implementation of a fixed-length-extension to measure fluorescent intensity in bioprocesses using an optical sensor [9863-18]

SESSION 5 PHARMACEUTICAL AND POINT-OF-CARE SENSING

9863 OK Application of the Black-Scholes equation in pharmaceutical engineering [9863-19]

9863 OM Molecular isotopic engineering (MIE): industrial manufacture of naproxen of predetermined stable carbon-isotopic compositions for authenticity and security protection and intellectual property considerations [9863-21]

9863 ON A paper based graphene-nanocauliflower hybrid composite for point of care biosensing [9863-22]

\section{SESSION 6 BIOMEDICAL AND PHYSIOLOGICAL SENSING}

986300 Special challenges and opportunities for application of bio-medical sensors (Invited Paper) [9863-23]

9863 OP Bridging the gap between sample collection and laboratory analysis: using dried blood spots to identify human exposure to chemical agents [9863-24]

$98630 Q \quad$ Integration of biochemical sensors into wearable biomaterial platforms [9863-25]

9863 OR Development of VIPER: a simulator for assessing vision performance of warfighters [9863-26]

9863 OS Comparative analysis of brain EEG signals generated from the right and left hand while writing [9863-27]

9863 OT The critical proportion of immune individuals needed to control hepatitis B [9863-28]

SESSION 7 TOWARD CLINICAL MONITORING

9863 OW Vessel extraction using the Buckmaster-Airy filter [9863-31]

9863 OX Electroencephalograph (EEG) study on self-contemplating image formation [9863-32]

$986302 \quad$ A highly sensitive pressure sensor using conductive composite elastomers with wavy structures [9863-35] 


\section{Authors}

Numbers in the index correspond to the last two digits of the six-digit citation identifier (CID) article numbering system used in Proceedings of SPIE. The first four digits reflect the volume number. Base 36 numbering is employed for the last two digits and indicates the order of articles within the volume. Numbers start with 00, 01, 02, 03, 04, 05, 06, 07, 08, 09, OA, OB...0Z, followed by 10-1Z, 20-2Z, etc.

Agarwal, Neelesh, 03

Al-Adhami, Mustafa, 0J

Arnold, Brad, 03, 04

Arnold, David P., OG

Bhargava, M., ON

Blake, Thomas A., OP

Burrs, S. L., ON

Cargill, Allison A., OE, $\mathrm{OQ}$

Castillo-Torres, Keisha Y., OG

Choa, Fow-Sen, 03, 04, OS, OX

Claussen, Jonathan C., 09, OE, OF, ON

Coleman, Rebecca M., OP

Convertino, M., 09

Coppock, Matthew B., 05

Coriell, S. R., 04

Crow, Brian S., OP

Cullum, Brian M., 03, 04, OB, OC

Daniele, Michael A., $0 Q$

Das, Suprem, 09

Dong, Hong, 08

Espinola, Richard L., OR

Familoni, Jide, OR

Farina, P., OM

Farrell, Mikella E., 05, OB

Garraud, Nicolas, OG

Gerlach, Elliot S., OI

Germane, Katherine L., 0

Gomes, C., 09, OF, ON

Hamelin, Elizabeth I., OP

Higuita, Esteban, OK

Hincapié-Palacio, Doracelly, OT

Holthoff, Ellen L., 08

Hondred, John A., 09, OE

Hong, Elliot, OX

Hopkins, R. H., 04

Hurley, Margaret M., 05, 08

Jamali Mahabadi, S. E., OS

Jandhyala, Sidhartha, $0 Q$

Jasper, J. P., OM

Johnson, Rudolph C., OP

Kiernan-Lewis, J., ON

Kostov, Yordan, OJ

Languirand, Eric R., OC

Liu, Sanchao, 0 I

Mackie, David M., Ol

McLamore, Eric S., 09, OE, OF, OG, ON

Meng, Qinglei, OS, OX

Mezes, P.S., OM

Moyer, Steve, OR
Mueller, Gregory, OR

Neil, Kathrine M., OE

Nguyen, Hung-Quang, OR

Ospina, Juan, OH, OT

Ozual, Abigail, $O Q$

Pearson, A., OM

Pellegrino, Paul M., 05, OB

Perez, Jonas W., OP

Rao, Govind, OJ

Rivers, Bruce A., OR

Rong, Y., OF, ON

Rossiter, Jonathan, $\mathrm{OZ}$

Ryan, Denise S., OR

Sabatelli, A. D., OM

Sanchez, Valentina, OW

Sardesai, Neha, OJ, OS

Sarkes, Deborah A., 05, 08, OB

Scarpa, Fabrizio, $0 Z$

Schwalb, N., ON

Servinsky, Matthew D., Ol

Shaner, Rebecca L., OP

Sia, Rose K., OR

Sidhu, R., OF, ON

Simon, Laurent, $\mathrm{OH}$

Singh, N. B., 03, 04

Small, Meagan C., 08

Sova, Stacey, 03

Stratis-Cullum, Dimitra N., 05, 08, OB

Strobbia, Pietro, OB

Su, Ching-Hua, 03, 04

Sun, Rujie, $0 Z$

Sund, Christian J., Ol

Terrell, Jessica L., 08

Thompson, Roger, OR

Vanegas, D. C., 09, OF, ON

Walper, Scott A., $O Q$

Weinrich, Michael, 00

Williams, Tim, OR

Zhang, Xiao-Chong, $\mathrm{OZ}$

Zu, Theresah N. K., Ol 
Proc. of SPIE Vol. $9863986301-6$

Downloaded From: https://www.spiedigitallibrary.org/conference-proceedings-of-spie on 26 Apr 2023 Terms of Use: https://www.spiedigitallibrary.org/terms-of-use 


\section{Conference Committee}

Symposium Chair

Ming C. Wu, University of California, Berkeley (United States)

Symposium Co-chair

Majid Rabbani, Eastman Kodak Company (United States)

Conference Chairs

Brian M. Cullum, University of Maryland, Baltimore County (United States)

Douglas Kiehl, Eli Lilly and Company (United States)

Eric S. McLamore, University of Florida (United States)

\section{Conference Program Committee}

Troy A. Alexander, U.S. Army Research Laboratory (United States)

Karl S. Booksh, University of Delaware (United States)

Liliana Braescu, University de Vest din Timisoara (Romania)

Jonathan C. Claussen, lowa State University (United States)

Mikella E. Farrell, U.S. Army Research Laboratory (United States)

Amethist S. Finch, U.S. Army Research Laboratory (United States)

Claudia Gärtner, microfluidic ChipShop GmbH (Germany)

Christopher D. Geddes, University of Maryland, Baltimore (United States)

Moinuddin Hassan, U.S. Food and Drug Administration (United States)

Ellen L. Holthoff, U.S. Army Research Laboratory (United States)

Ilko K. Ilev, U.S. Food and Drug Administration (United States)

K. D. Mandal, Banaras Hindu University (India)

T. Joshua Pfefer, U.S. Food and Drug Administration (United States)

Noriko Satake, UC Davis Medical Center (United States)

Shiv K. Sharma, University of Hawai'i (United States)

Narsingh B. Singh, University of Maryland, Baltimore County (United States)

Dimitra N. Stratis-Cullum, U.S. Army Research Laboratory (United States)

Mary E. Stuart, University of Maryland, Baltimore County (United States)

Michael Weinrich, National Institutes of Health (United States)

Ryan J. White, University of Maryland, Baltimore County (United States) 


\section{Session Chairs}

1 Smart Materials for Sensing

Mikella E. Farrell, U.S. Army Research Laboratory (United States)

Douglas Kiehl, Eli Lilly and Company (United States)

2 Bioinspired Receptors and Sensing Platforms

Ellen L. Holthoff, U.S. Army Research Laboratory (United States)

Douglas Kiehl, Eli Lilly and Company (United States)

3 Enabling Technologies and Sensing Platforms

Douglas Kiehl, Eli Lilly and Company (United States)

Mikella E. Farrell, U.S. Army Research Laboratory (United States)

4 Bacterial \& Metabolic Sensing

Eric S. McLamore, University of Florida (United States)

Douglas Kiehl, Eli Lilly and Company (United States)

5 Pharmaceutical and Point-of-Care Sensing

Douglas Kiehl, Eli Lilly and Company (United States)

Jonathan C. Claussen, Iowa State University (United States)

Dimitra N. Stratis-Cullum, U.S. Army Research Laboratory

(United States)

6 Biomedical and Physiological Sensing

Michael Weinrich, National Institutes of Health (United States)

Jianting Wang, U.S. Food and Drug Administration (United States)

7 Toward Clinical Monitoring

Douglas Kiehl, Eli Lilly and Company (United States)

Brian M. Cullum, University of Maryland, Baltimore County (United States) 